\title{
Samlivsråd anno 1931
}

\begin{abstract}
Dr. Dedichens råd om hvordan man skal mestre det vanskelige samlivet bygger på en menneskealders betroelser. Hvordan mannen teknisk skal gripe saken an, beskrives med nærmest krigslignende metaforer. Kvinnen rådes til å forføre sin mann: «Hvis kvinnene visste, hvor sterkt det polygame drag i mannens natur ofte er, og hvor ofte han fristes på den aller behendigste måte, så vilde de kanskje forstå, at det kunne lønne sig for dem å opta konkurransen med de frie fugler.» Det hele avsluttes med et par setninger om hva kjærlighet er - men her er den gode doktor så blyg at han tar dem på fransk (Tidsskr Nor Lægeforen 1931; 51: 369-72).
\end{abstract}

\section{Frigide fruer og klodrianer til ektemenn.}

\section{Av Henrik A. Th. Dedichen.}

En æret kollega har som «Landslæge» sluttet sig til overlæge Nitters uttalelse om, at størsteparten av kvinnene ikke tilfredsstilles ordentlig under samleiet. Derom vet vi nu foreløpig ikke noget sikkert. Det er ikke mange læger - ser det ut til -, som spør om slikt, og enda ferre spør riktig. Derfor får de ikke ordentlig svar. Det skal villig innrømmes, at emnet hører til de vanskeligste, en kan gi sig i kast med; men det gjelder både mann og kvinne, at her kan de uttale sig med trygghet, visse på å bli riktig forstått, så føler de det som en befrielse en gang å kunne få tale ut - og da er det meget rart, man får høre, og det meste støtter overlægens påstand.

(...) Der hopper visst mangen ung pike i brudeseng uten å vite, hvad der egentlig venter henne der. Undertiden får hun en mann, som er - også han - debutant på elskovsstien, og jeg tror, hun - tross alt - skal takke til. Mange mannfolk er ganske visst nogen store klodrianer, og dertil kanskje også tåpelige, så de ikke forstår, det lønner sig ikke på dette området å være egoist. Men, når «Landslæge» forteller, at en brudgom - til og med en kollega - tok gift bryllupsnatten, fordi han fikk en ejaculatio præcox, tror jeg det må være et eventyr. Den oplevelse må vel snarere kalles fysiologisk enn patologisk, og en time senere (eller endog før!) vilde han sikkert være annet til mann.

Hymen er ganske visst ikke noget bombesikkert vern mot en inntrengende erobrer; men den kan volde bryderi nok. Hvis den ikke sprenges helt ved første stormløp og helst får ligge nogen dager urørt, før neste angrep kommer, kan man komme til å gjøre så smertefulle erfaringer om det ekteskapelige samliv, at en vaginisme er resultatet. Heldigst er begge parter, om han samtidig får en dyp revne i præputium, for så kanskje de begge venter med videre øvelser til sårene er helet. Endeløse er rekken av de vittigheter, som er ødslet på den mere eller mindre uheldige deflorasjon - den, som i virkeligheten ofte nok er en stillferdig tragedie, under hvilken mange menneskers hele livslykke lider skibbrudd. (...)

Der er noget, man kunde fristes til å kalle samleiets teknikk, men i det fag gis der mig bekjent ingen lærebok. Mange vil dog med utbytte lese Emil Rodes artikkel i dette tidsskrift 1896. Hvad skal da en stakkars uerfaren yngling gjøre - og sådanne finnes virkelig. Jeg kjenner flere tilfelle, hvor han efter en kort mislykket forsøksrekke har opgitt saken helt, så der i et mangeårig ekteskap ikke har funnet et eneste virkelig samleie sted. Er det ikke komisk? Jeg finder det nu tvertom i høieste grad tragisk, nesten likeså tragisk og undertiden vel så tragisk, som når hun undfanger gang på gang uten nogen sinne å ha erfart, hvad orgasme er. Jeg skal vel vokte mig for å tale inngående om psykoanalyse - man får inte reta djuren - men skjønt vi sinssykelæger på dette område betraktes som rene legmenn, så har vi nu sett litt og gjort våre erfaringer vi med. Og dog er der ikke tvil om, at likeså sikkert som det er, at intet kan, under de riktige forutsetninger, binde mennesker tryggere sammen enn samleiet og dets resultat, barnene, likeså sikkert er det, at nettop det

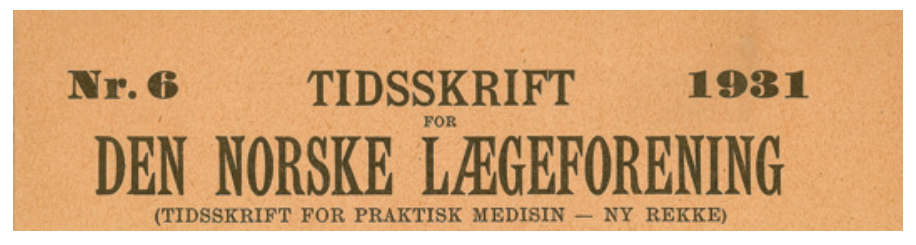

kan skape en uoverstigelig avgrunn mellem dem, gjøre dem til uforsonlige fiender - motbydelige for hverandre i det daglige samvær. Og så skulde der til en begynnelse rimeligvis ikke mere til enn litt kyndig varsomhet, litt menneskeklok forståelse av, at et harmonisk samspil her krever medvirken av to. En mann kan ikke gå til et samleie, uten at han psykisk og fysisk er innstillet på det. Han skulde aldri glemme, at en kvinne har det likedan, hvis hun skal kunne leve med, og ikke bare bli ham det mekaniske instrument, hans neve i nødsfall kan yde ham sin hjelp med nesten like godt. Mellem to, som virkelig holder av hinannen, er alle - uten undtagelse alle - kjærtegn tillatt, som kan hitføre den forberetthet, som er nødvendig for et ideelt samleie. Van Svietens ord om Maria Theresia - «ego mehercule credo, vulvam sacratissimae Majestatis ante coitum longius esse titillendam» - rummer i all enkelhet en dyp sannhet, som kan gjøre tusener av mennesker lykkelige.

Jeg har her vesentlig talt om den kvinnelige frigiditet og stilltiende forutsatt, at mannen nesten alltid er potent og den, som tar initiativet. Man går alminneligvis ut fra, - men det er ganske upsykologisk - at det er hans plikt hele livet igjennem alltid å lokkes bare av den ene samme kvinne, som han nu engang har bundet sig til. Hvis kvinnene visste, hvor sterkt det polygame drag i mannens natur ofte er, så vilde de kanskje forstå, at det kunde lønne sig for dem å opta konkurransen med de frie fugler. Mangen en hustru, som pint av skinssyke er blitt redd for, at nogen skulde stjele mannen fra henne, har-kanskje veiledet av et klokt råd - opdaget, at også hun kunde forføre sin mann, og det med rikere utbytte enn om hun nådigst nu og da tilsteder ham adgang til sitt leie. Skjønt mannen som regel meget snart opdager hennes hensikt, er det ham dog en henrivende oplevelse å bli forført av sin egen kone, og det desto mere, jo finere hennes snarer legges. Det skulde kvinnene betenke og anstrenge sig for en gang iblandt å være nye for sine menn og derved erobre dem tilbake, når vanelivet truet med å la dem gli altfor langt bort.

Hvad jeg her har fremholdt, bygger på en menneskealders overordentlig tallrike betroelser. Og ingen må tro, de skriver sig fra sinnssyke alene. Tvertom. Fåtallet fra dem. Det kreves bare, at den, hvem skoen trykker, får tillit, og meddelelsene kommer som en foss. Et forpint sinn er lettet og takknemlig, selv hvor man ingen større hjelp kan bringe, fordi den aller siste vanskelighet ligger i det forhold, som en åndfull franskmann har uttrykt således:

Qu'est-ce que c'est l'amour? L'échange de deux fantaisies et le contact de deux épidermes. 